POLITEKNIK NEGERI NUSA UTARA

\title{
APLIKASI HORMON PERTUMBUHAN REKOMBINAN UNTUK MENINGKATKAN \\ LAJU PERTUMBUHAN IKAN KAKAP (Lutjanus Sp.) PADA KERAMBA JARING APUNG DI TELUK TALENGEN
}

\author{
Application of Recombinant Growth Hormones to Increase The Growth Rate of Lutjanus Sp. \\ in Floating Net Cages in Talengen Bay
}

\author{
Aprelia Martina Tomasoa, Walter Balansa, Krisan Salendeho \\ Program Studi Teknologi Budidaya Ikan Jurusan Perikanan dan Kebahariaan Politeknik Negeri Nusa Utara \\ Email: apriltomasoa@gmail.com
}

\begin{abstract}
Abstrak: Budidaya ikan kakap sering terkendala dengan kurang tersedianya pakan rucah secara kontinyu dan berkelanjutan, karena pakan rucah tersedia secara musiman. Budidaya ikan kakap harus diselingi dengan pemberian pakan pelet, apalagi pakan pelet yang diperkaya dengan hormon pertumbuhan rekombinan dapat menjadi salah satu solusi. Mempercepat laju pertumbuhan ikan dapat dilakukan dengan pemberian hormon pertumbuhan rekombinan. Hormon tersebut dijadikan sebagai sumplemen pakan bagi ikan maupun udang. Tujuan penelitian ini adalah untuk meningkatkan laju pertumbuhan ikan kakap menggunakan hormon pertumbuhan rekombinan yang dibudidayakan dengan sistem keramba jaring apung di Teluk Talengen. Tahapan penelitian terdiri dari persiapan wadah dan ikan uji, pembuatan pakan dan pemeliharaan selama 30 hari. Perlakuan yang dilakukan adalah dosis hormon pertumbuhan rekombinan yang diaplikasikan ke pakan dan diberikan pada ikan kakap. Dosis yang diberikan adalah : $0 \mathrm{mg} / \mathrm{kg}, 2 \mathrm{mg} / \mathrm{kg}, 3 \mathrm{mg} / \mathrm{kg}$, dengan tiga kali ulangan. Ikan kakap yang digunakan berukuran $3-5 \mathrm{~cm}$ dengan padat tebar 10 ekor per wadah. Dosis hormon pertumbuhan rekombinan akan dicoating menggunakan putih telur dan disemprot ke pakan. Pemberian pakan dilakukan secara at satiation dengan frekuensi pemberian sebanyak 2 kali pada pagi dan sore hari. Hasil penelitian memperlihatkan perlakuan terbaik yaitu dosis $3 \mathrm{mg} / \mathrm{kg}$ pakan meningkatkan bobot tubuh $(8,8 \mathrm{gr})$, SGR $(3,43 \%)$, EP $(28,3 \%)$ dan SR (100\%) dibandingkan perlakuan kontrol. Hal tersebut menunjukkan hormon pertumbuhan rekombinan memberi pengaruh positif meningkatkan laju pertumbuhan dan survival rate ikan kakap selama 30 hari pemeliharaan.
\end{abstract}

Kata kunci: coating, hormon pertumbuhan rekombinan, keramba jaring apung, Lutjanus sp, pembesaran

Abstract: Snapper cultivation is often constrained by the lack of continuous and sustainable feed availability, because trash feed is readily available. The cultivation of snapper fish must be interspersed with providing pellet feed, moreover pellet feed enriched with recombinant growth hormone can be a solution. Accelerating the growth rate of fish can be done by offering recombinant growth hormone. This hormone is used as a supplement to feed for fish and shrimp. The aim of this study was to increase the growth rate of snapper using recombinant growth hormone cultivated with floating net cage system in Talengen Bay. Stages of taking care of research from containers and test fish, making feed and maintaining it for 30 days. The treatment is a recombinant growth hormone which is applied to feed and given to snapper. The doses given were: $0 \mathrm{mg} / \mathrm{kg}, 2 \mathrm{mg} / \mathrm{kg}, 3 \mathrm{mg} / \mathrm{kg}$, with three replications. The snapper used is 3-5 $\mathrm{cm}$ in size with a stocking density of 10 fish per container. The dose of recombinant growth hormone will be coated using egg white and sprayed into the feed. Feeding is done occasionally with a frequency of offering 2 times in the morning and evening. The results of the best treatment treatment, namely the dose of $3 \mathrm{mg} / \mathrm{kg}$ of feed increased body weight ( $8.8 \mathrm{gr})$, SGR (3.43\%), EP (28.3\%) and SR (100\%) compared to control treatment. This shows that the growth of recombinant growth hormone has a positive effect on increasing the growth rate and survival of snapper for 30 days of rearing.

Keyword: coating, floating cage net, growthout, recombinant growth hormone, Lutjanus sp. 
15 Jurnal Ilmiah Tindalung, Volume 7, Nomor 2, November 2021, hlm. 14-21

\section{PENDAHULUAN}

Ikan kakap (Lutjanus sp.) sebagai salah satu komoditas budidaya laut memiliki nilai ekonomi tinggi diantaranya; memiliki kandungan omega-3, kandungan protein sebesar $15-20 \%$ dan lemak sebesar 5\% (Natsir \& Latifa, 2018; Purba et al., 2016), warna daging putih, dapat dibudidayakan diair laut dan payau serta memiliki pasaran yang luas baik internasional, nasional maupun lokal. Ikan kakap yang diekspor biasanya dalam bentuk fresh dan frozen ke Amerika Serikat, Italia, Spanyol, Prancis, Australia dan negara-negara Timur Tengah (Hardianti et al., 2016; KKP, 2020).

Usaha pengembangan yang dilakukan saat ini untuk budidaya ikan kakap adalah dengan melakukan demonstration farm (demfarm) di keramba jaring apung (KJA). KJA adalah salah wadah budidaya yang cukup ideal, yang ditempatkan di badan air dalam seperti waduk, danau dan laut. KJA merupakan wadah untuk penerapan budidaya dengan sistem intensif untuk kelompok ikan maupun non ikan pada fase pendederan sampai pembesaran. Teluk Talengen memiliki karakteristik lingkungan perairan yang aman terlindung dari ombak besar serta masih ditemukan beberapa ekosistem pesisir dan laut seperti ekosistem manggrove, padang lamun hingga terumbu karang membuat kualitas dari perairan ini layak untuk dilakukan budidaya ikan/non ikan. Penelitian yang dilakukan oleh Silalahi et al. (2015) dan Schaduw \& Ngangi (2015) melaporkan Teluk Talengen memiliki kondisi lingkungan dan parameter kualitas air yang layak untuk budidaya ikan dan karang hias serta budidaya rumput laut.

Windarto et al. (2019) melaporkan sulitnya penyediaan pakan rucah secara kontinyu dalam jumlah yang cukup menjadi salah satu masalah dalam pembesaran ikan kakap. Hal dikarenakan pakan rucah tersedia secara musiman, ketika musim ikan melimpah pakan rucah akan tersedia dalam jumlah yang melimpah tetapi ketika musim susah ikan maka pakan rucah tidak tersedia bahkan akan menjadi kompetitor dengan manusia untuk pemenuhan konsumsi ikan. Sehingga salah satu solusi yang mampu menyediakan pakan ikan kakap secara berkelanjutan yaitu melalui aplikasi hormon pertumbuhan rekombinan pada pelet komersial untuk meningkatkan laju pertumbuhan agar kebutuhan pakan tetap terpenuhi dan memperpendek waktu budidaya.

Hormon pertumbuhan rekombinan merupakan inovasi teknologi dibidang perikanan yang memiliki potensi sebagai pakan suplemen yang dapat memberikan percepatan pertumbuhan ikan budidaya (Alimuddin et al., 2010), meningkatkan kelulusan hidup ikan melalui sistem peningkatan kekebalan tubuh terhadap penyakit dan stress (McCormick, 2001). Menurut Ihsanudin et al. (2014) hormon pertumbuhan merupakan salah satu hormon hidrofilik polipeptida yang tersusun atas asam amino yang dapat digunakan untuk memacu pertumbuhan ikan. Penelitian yang dilakukan dengan pemberian hormon pertumbuhan rekombinan telah diuji pada coho salmon dan chum salmon (Moriyama \& Kawauchi, 1990), ikan nila merah (Acosta et al., 2007), udang vaname (Santiesteban et al., 2010; Subaidah et al., 2012), ikan gurami (Irmawati et al., 2012), ikan sidat (Handoyo et al., 2012), ikan mas (Tomasoa \& Laodini, 2018) dan ikan baung (Saputra et al., 2017). Tujuan penelitian ini untuk meningkatkan laju pertumbuhan ikan kakap menggunakan hormon pertumbuhan rekombinan yang dibudidayakan dengan sistem keramba jaring apung di Teluk Talengen. 


\section{METODE}

\section{Alat dan Bahan}

Tabel 1. Alat dan bahan penelitian

\begin{tabular}{|l|l|}
\hline \multicolumn{1}{|c|}{ Alat } & \multicolumn{1}{c|}{ Bahan } \\
\hline Keramba jaring apung & Ikan kakap \\
\hline Kurungan jarring & $\begin{array}{l}\text { Hormon pertumbuhan } \\
\text { rekombinan }\end{array}$ \\
\hline Timbangan digital & Telur ayam \\
\hline Gelas ukur & NaCl 0,9\% \\
\hline Penggaris & Pakan Megami \\
\hline Sibu-sibu & Stabilizer \\
\hline
\end{tabular}

\section{Tahapan penelitian}

Penelitian dilaksanakan dalam beberapa tahap, uraian tahapan tersebut sebagai berikut :

\section{Persiapan wadah}

Wadah yang digunakan pada penelitian ini yaitu kurungan jaring sebanyak 3 unit yang didesain setiap unit memiliki 3 kotak berukuran 1x1x1 m yang diletakkan di dalam KJA berukuran 4x4 m. Kurungan jaring dan jaring KJA dibersihkan terlebih dulu menggunakan air tawar dan dijemur hingga kering untuk menghilangkan substrat yang menempel pada jaring

\section{Persiapan ikan kakap}

Ikan yang digunakan adalah ikan kakap (Lutjanus sp.) berasal dari perairan disekitar Teluk Talengen. Ikan kakap yang digunakan disortir dan dipilih memiliki ciri-ciri tubuh yang tidak luka dan tidak cacat dengan ukuran ikan 3-5 cm. Ikan yang telah disortir akan ditebar pada masingmasing kotak kurungan jaring sebanyak 10 ekor. Sebelum dilakukan perlakuan, ikan kakap akan diaklimatisasi awal pada wadah KJA selama 3 hari, aklimatisasi pakan pelet selama 7 hari dan aklimatisasi akhir selama 4 hari

3. Pembuatan pakan berhormon
Aplikasi hormon pertubuhan rekombinan dilakukan dengan metode oral. Aplikasi dosis hormon pertumbuhan pada pakan Megami (pakan komersil) sesuai rancangan penelitian $(0 \mathrm{mg} / \mathrm{kg}, 2$ $\mathrm{mg} / \mathrm{kg}$ dan $3 \mathrm{mg} / \mathrm{kg}$ pakan), dilakukan coating menggunakan putih telur sebagai binder dan dimasukkan ke dalam botol spayer. Kemudian campuran setiap perlakuan disemprotkan ke pakan pelet hingga rata dan dikeringanginkan selama 30 menit. Pakan disimpan dan siap digunakan

4. Pemeliharaan ikan

Pemeliharaan ikan dilakukan selama 30 hari. Sebelum dilakukan perlakuan dan pemeliharaan akan dilakukan sampling awal, meliputi: bobot tubuh awal, panjang tubuh awal dan jumlah ikan tiap kotak kurungan jaring. Pemberian pakan pada ikan kakap secara at satiation dengan melakukan frekuensi pemberian pakan 2 kali sehari pada pagi dan sore. Setiap minggu pemeliharaan akan dilakukan pengukuran kualitas air, meliputi: suhu, $\mathrm{pH}$, salinitas, dan kekeruhan air. Pengukuran kualitas air dapat dilihat pada Tabel 2.

Tabel 2. Pengukuran kualitas air

\begin{tabular}{|c|l|l|}
\hline No & \multicolumn{1}{|c|}{ Parameter } & \multicolumn{1}{|c|}{ Hasil Pengukuran } \\
\hline 1 & Salinitas & $32-35 \mathrm{ppt}$ \\
\hline 2 & Suhu & $28,7-32,1^{\circ} \mathrm{C}$ \\
\hline 3 & $\mathrm{pH}$ & $7-8$ \\
\hline 4 & Kekeruhan air & $4,19-5,2$ NTU \\
\hline
\end{tabular}

\section{Parameter Uji}

Parameter uji yang dilakukan dalam penelitian ini sebagai berikut :

\section{Bobot Tubuh}

Bobot tubuh merupakan nilai yang dihitung berdasarkan selisih berat ikan pemeliharaan dengan berat akhir pemeliharaan dan berat awal pemeliharaan dengan rumus : 


\[ \mathbf{W}=\mathbf{W}_{\mathbf{t}}-\mathbf{W}_{\mathbf{0}} \]
Keterangan :
$\mathrm{W} \quad=$ Pertumbuhan bobot tubuh $(\mathrm{gr})$
$\mathrm{W}_{\mathrm{t}} \quad=$ Bobot ikan akhir pemeliharaan $(\mathrm{gr})$
$\mathrm{W}_{0}=$ Bobot ikan awal pemeliharaan $(\mathrm{gr})$

\section{Laju Pertumbuhan Spesifik (SGR)}

Laju pertumbuhan spesifik diukur dengan pengambilan data saat awal dan akhir penelitian dengan rumus :

$$
\mathrm{SGR}=\frac{\ln W t-\ln W 0}{t} x 100 \%
$$

Keterangan :

SGR = Laju pertumbuhan spesifik (\%)

$\mathrm{W}_{\mathrm{t}} \quad=$ Bobot ikan akhir pemeliharaan $(\mathrm{gr})$

$\mathrm{W}_{0} \quad=$ Bobot ikan awal pemeliharaan $(\mathrm{gr})$

$\mathrm{t}=$ Lama waktu pemeliharaan (hari)

\section{Efisiensi Pakan}

Efisiensi pakan dihitung menggunakan rumus :

$$
\mathbf{E P}=\frac{(W t+D)-W 0}{F} x 100 \%
$$

Keterangan :

$\mathrm{EP} \quad=$ Efisiensi pakan $(\%)$

$\mathrm{W}_{\mathrm{t}} \quad=$ Bobot ikan akhir pemeliharaan $(\mathrm{gr})$

$\mathrm{W}_{0} \quad=$ Bobot ikan awal pemeliharaan $(\mathrm{gr})$

\section{HASIL DAN PEMBAHASAN}

Dari hasil penelitian yang diperoleh menunjukkan pengaruh positif dari aplikasi hormon pertumbuhan rekombinan pada ikan kakap selama 30 hari masa pemeliharaan. Hasil penelitian diantaranya yaitu;

\section{Bobot tubuh}

Rata-rata bobot tubuh ikan kakap setiap minggu dapat dilihat pada Gambar 1. Peningkatan bobot tubuh ikan kakap semakin meningkat seiring dengan masa pemeliharaan dan dosis hormon pertumbuhan yang diberikan.
D = Jumlah ikan yang mati

$\mathrm{F} \quad$ = Jumlah pakan yang dikonsumsi

\section{Tingkat Kelangsungan Hidup (SR)}

Tingkat kelangsungan hidup merupakan persentase jumlah ikan hidup pada akhir pemeliharaan dibandingkan dengan jumlah ikan pada awal pemeliharaan. Berikut rumus perhitungan tingkat kelangsungan hidup :

$$
\mathrm{SR}(\%)=\frac{N 0}{N t} \times 100
$$

Keterangan:

SR : Tingkat kelangsungan hidup (\%)

$\mathrm{N}_{\mathrm{t}} \quad$ : Jumlah ikan di akhir pemeliharaan

$\mathrm{N}_{0} \quad$ : Jumlah ikan di awal pemeliharaan

\section{Analisis Data}

Data hasil pengukuran parameter pengamatan yang diperoleh akan dianalisis secara deskriptif. Data hasil yang diperoleh akan disajikan dalam histogram untuk menjelaskan pengaruh pemberian hormon pertumbuhan rekombinan terhadap laju pertumbuhan ikan kakap selama 30 hari masa pemeliharaan.

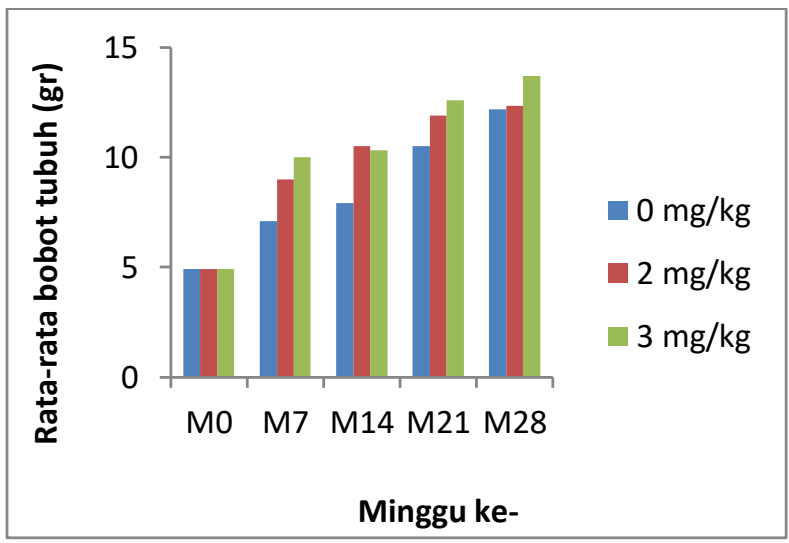

Gambar 1. Rata-rata bobot tubuh ikan kakap setiap minggu 


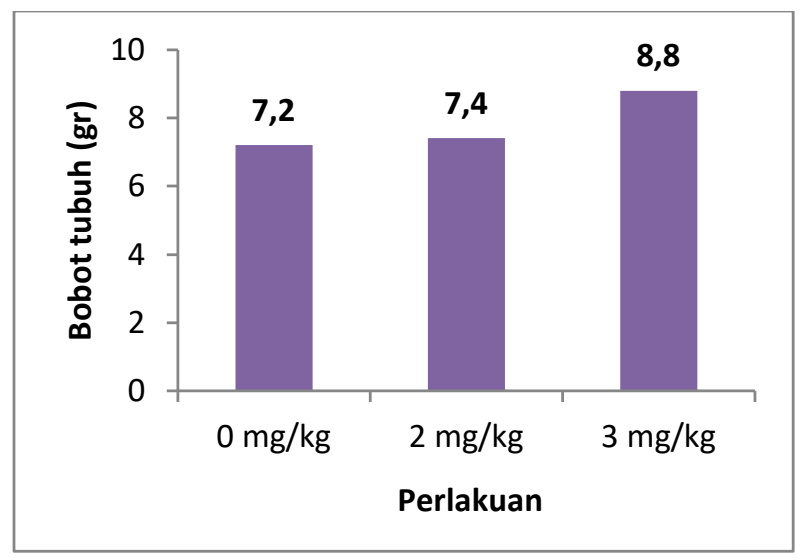

Gambar 2. Bobot tubuh ikan kakap

Gambar 2 menunjukkan pertumbuhan bobot tubuh ikan kakap yang tertinggi pada perlakuan dosis $3 \mathrm{mg} / \mathrm{kg}$ sebesar 8,8 gr dan diikuti oleh perlakuan dosis $2 \mathrm{mg} / \mathrm{kg}$ sebesar 7,4 gr dibandingkan dengan perlakuan kontrol sebesar 7,2 gr. Hasil pertumbuhan bobot tubuh ikan menunjukkan pengaruh positif hormon pertumbuhan rekombinan dalam merangsang pertumbuhan somatik ikan kakap menjadi daging ikan. Masuknya rGH ke tubuh ikan melalui pakan yang diberikan menyebabkan terjadinya hidrolisis disaluran pencernaan oleh enzim proteolysis sehingga lebih mudah diserap oleh tubuh (Antoro et al., 2014).

\section{Laju pertumbuhan spesifik (SGR)}

Hasil SGR dapat dilihat pada Gambar 3. Laju pertumbuhan spesifik ikan kakap yang diberi hormon pertumbuhan rekombinan yang tertinggi sebesar $3,43 \%$ (dosis $3 \mathrm{mg} / \mathrm{kg}$ ) bila dibandingkan dengan ikan kakap yang beri perlakuan kontrol sebesar $2,63 \%$.

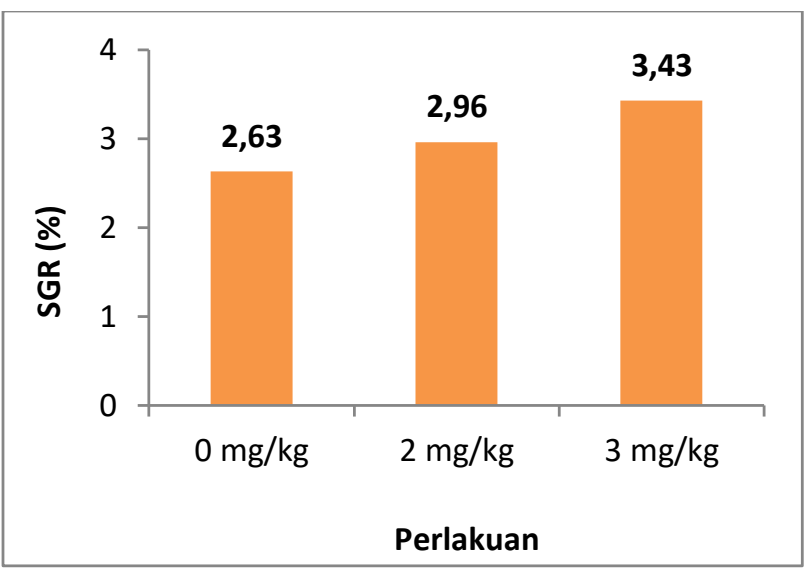

Gambar 3. Laju pertumbuhan spesifik ikan kakap.

\section{Efisiensi pakan}

Perhitungan efisiensi pakan dilakukan untuk mengevaluasi pakan yang diberikan pada ikan kakap apakah efisien dalam menunjang laju pertumbuhan ikan atau tidak. Efisiensi pakan dapat dilihat pada Gambar 4. Persentase efisiensi pakan tertinggi pada perlakuan $3 \mathrm{mg} / \mathrm{kg}$ sebesar 28,3\%, perlakuan $2 \mathrm{mg} / \mathrm{kg}$ sebesar 22,5\% dibandingkan dengan perlakuan kontrol $0 \mathrm{mg} / \mathrm{kg}$ sebesar 19,1\%. Efek dari pemberiaan rGH pada ikan dapat dilihat dari besarnya nilai efesiensi pakan dalam pembentukkan massa otot atau daging dan lama cepatnya respons ikan dalam mengkonsumsi pakan (Ramayani et al., 2016). Hal ini menunjukkan ikan kakap yang diberi perlakuan hormon pertumbuhan rekombinan efisien dalam mengkonsumsi pakan yang diberikan sehingga menunjang laju pertumbuhan serta dapat mengurangi jumlah pakan yang digunakan dalam proses budidaya. Sejalan dengan Zulpikar et al. (2018) meningkatkan nilai efisiensi pakan menggunakan dosis $\mathrm{rGH} 6 \mathrm{mg} / \mathrm{kg}$ pakan sebesar 72,06\% pada ikan bawal bintang. 


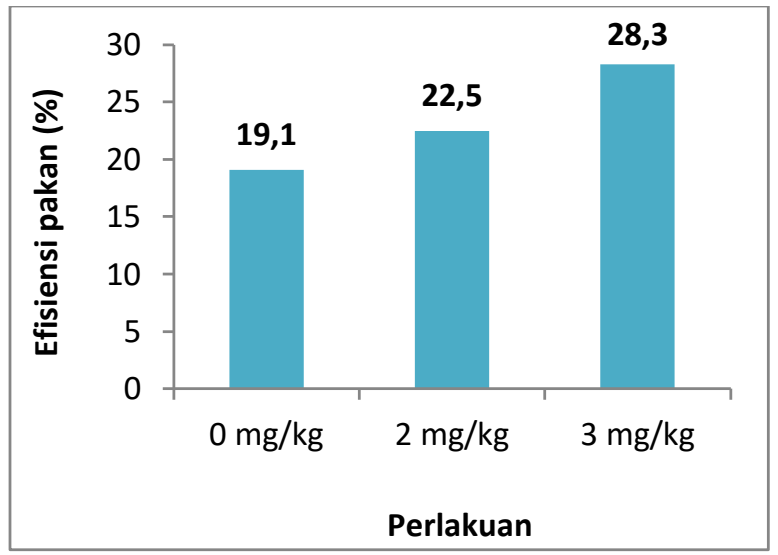

Gambar 4. Efisiensi pakan ikan kakap

\section{Tingkat kelangsungan hidup}

Gambar 5 memperlihatkan SR ikan kakap selama masa pemeliharaan dimana persentase perlakuan $3 \mathrm{mg} / \mathrm{kg}$ yang tertinggi mencapai $100 \%$, perlakuan $2 \mathrm{mg} / \mathrm{kg}$ sebesar $96 \%$ dan perlakuan kontrol $0 \mathrm{mg} / \mathrm{kg}$ sebesar 90\%. Menurut Mulyani (2014) dalam Tomasoa \& Azhari (2019) menyebutkan bahwa nilai SR yang baik jika $>50 \%$ dan tidak baik jika 30\%. Selanjutnya Tomasoa \& Azhari (2019) menambahkan ketersediaan pakan dan kondisi media pemeliharaan yang baik dapat mempengaruhi SR. Selain itu hormon pertumbuhan rekombinan menunjukkan pengaruh tidak saja dapat merangsang pertumbuhan namun juga dapat meningkatkan sistem imun ikan kakap sehingga SR yang dihasilkan sangat baik ( $>50 \%)$ dan mencapai $100 \%$.

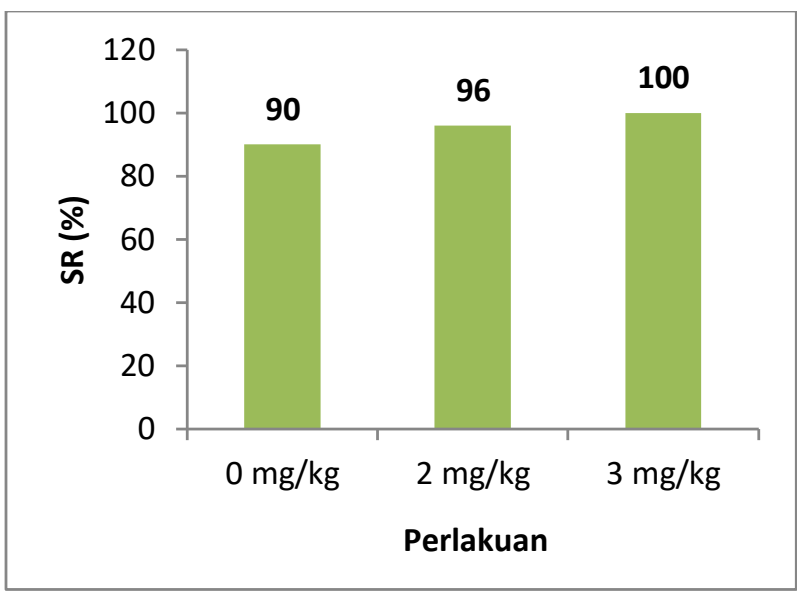

Gambar 5. Tingkat kelangsungan hidup ikan kakap

\section{KESIMPULAN}

Peningkatkan laju pertumbuhan ikan kakap semakin tinggi seiring dengan semakin tinggi dosis hormon pertumbuhan rekombinan yang diberikan. Perlakuan dosis hormon pertumbuhan rekombinan $3 \mathrm{mg} / \mathrm{kg}$ pakan merupakan perlakuan dosis terbaik meningkatkan pertumbuhan bobot tubuh $(8,8 \mathrm{gr})$, SGR $(3,43 \%)$, EP $(28,3 \%)$ dan SR (100\%) dibandingkan perlakukan lainnya.

\section{DAFTAR RUJUKAN}

Acosta J, Morales R, Morales A, Alonso M, Estrada MP. 2007. Pichia pastoris expressing recombinant tilapia growth hormone accelerates the growth of tilapia. Biotechnol Lett. 29: 1671-1676 
Alimuddin, Lesmana I, Sudrajat AO, Carman O, Faizal I. 2010. Production and bioactivity potential of three recombinant growth hormones of farmed fish. Indones Aquac J. 5: 11-16

Antoro S, Junior MZ, Alimuddin A, Suprayudi MA, Faizal I. 2014. Growth, biochemical composition, innate immunity and histological performance of the juvenile humpback grouper (Cromileptes altivelis) after treatment with recombinant fish growth hormone. Aquaculture Research. 1-13

Handoyo B, Alimuddin, Utomo NBP. 2012. Pertumbuhan, konversi, retensi pakan, dan proksimat tubuh benih ikan sidat yang diberi hormon pertumbuhan rekombinan ikan kerapu kertang melalui perendaman. Jurnal Akuakultur Indonesia. 11(2): 132-140

Hardianti Q, Rusliadi, Mulyadi. 2016. Effect of feeding made with different composition on growth and survival seeds of Barramudi (Lates calcalifer, Bloch). Jurnal Online Mahasiswa. 3(2): 1-10

Irmawati, Alimuddin, Zairin MJr, Suprayudi MA, Wahyudi AT. 2012. Peningkatan laju pertumbuhan benih ikan gurami (Osphronemus goramy Lac.) yang direndam dalam air yang mengandung hormon pertumbuhan ikan mas. Jurnal Iktiologi Indonesia. 12(1): 13-23

Ishanudin I, Rejeki S, Yuniarti T. 2014. Pengaruh pemberian rekombinan hormon pertumbuhan (rGH) melalui metode oral dengan interval waktu yang berbeda terhadap pertumbuhan dan kelulushidupan benih ikan nila larasati (Oreochromis niloticus). Journal of Aquaculture Management and Technology. 3(2): 94-102

[KKP] Kementerian Kelautan dan Perikanan. 2020. Genjot Produksi, KKP Jadikan Kabupaten Meranti Pusat Kawasan Budidaya Kakap Putih Nasional. https://kkp.go.id/artikel/17085-genjotproduksi-kkp-jadikan-kabupaten-merantipusat-kawasan-budidaya-kakap-putih-nasional Akses : 1 April 2020

McCormick SD. 2001. Endocrine Control of Osmoregulation in Teleost Fish. Amer Zool 41: 781-794. Model. Aquacult. 204: 371-38
Moriyama S, Kawauchi H. 1990. Growth stimulation of juvenile salmonids by immersion in recombinant salmon growth hormone. Nippon Suisan Gakkaishi. 56(1): 31-34

Natsir NA \& Latifa S. 2018. Analisis kandungan protein total ikan kakap merah dan ikan kerapu bebek. Jurnal Biology Science \& Education. 7(1): 49-55

Purba EP, Ilza M, Leksono T. 2016. Study penerimaan konsumen terhadap steak (fillet) ikan kakap putih flavor asap. Jurnal Online Mahasiswa. 3(2): 1-11

Ramayani santi, Iskandar Putra, Mulyadi, 2016. Pemberian Hormon Rekombinan terhadap Pertumbuhan dan Kelulushidupan Ikan Baung (Hemibagrus nemurus) yang Dipelihara dalam Sistem Akuaponik, Jurnal Online Fakultas Perikanan dan Ilmi Kelautan, volume 3, nomor 02, halaman 1-8.

Santiesteban D, Martín L, Arenal A, Franco R, Sotolongo J. 2010. Tilapia growth hormone binds to a receptor in brush border membrane vesicles from the hepatopancreas of shrimp (Litopenaeus vannamei). Aquaculture. 306(14): 338-342

Saputra A, Tarsim, Elisdiana Y. 2017. Pengaruh perendaman ikan baung (Hemibagrus nemurus) pada umur yang berbeda dalam hormon pertumbuhan rekombinan (rGH) dengan dosis yang berbeda terhadap pertumbuhan dan kelulushidupan. Jurnal Sains Teknologi Akuakultur. 1(2): 127-132

Schaduw JNW \& Ngangi E. 2015. Karakteristik lingkungan perairan Teluk Talengen Kabupaten Kepulauan Sangihe sebagai kawasan budidaya rumput laut Kappaphycus alvarezii. Budidaya Perairan. 3(2): 29-44

Silalahi DRA, Ngangi ELA, Undap SL. 2015. Kelayakan lokasi untuk pengembangan budidaya karang hias di Teluk Talengan Kabupaten Kepulauan Sangihe. Budidaya Perairan. 3(1): 108-113

Subaidah S, Carman O, Sumantadinata K, Sukenda, Alimuddin. 2012. Respons pertumbuhan dan ekspresi gen udang vaname (Litopenaeus vannamei) setelah direndam dalam larutan hormon pertumbuhan rekombinan ikan kerapu kertang. Jurnal Riset Akuakultur. 7(3): 337352 
Tomasoa AM \& Azhari D. 2019. Pemanfaatan tepung biji pepaya (Carica papaya) terhadap respons pertumbuhan dan tingkat kelangsungan hidup ikan nila (Oreochromis niloticus). Jurnal MIPA Online. 8(3): 160-163

Tomasoa AM \& Laodini E. 2018. Pemberian recombinant Growth Hormone melalui metode perendaman terhadap pertumbuhan dan tingkat kelulusan hidup larva ikan mas (Cyprinus carpio). Jurnal Tindalung. 4(2): 7882
Windarto S, Hastuti S, Subandiyono, Nugroho RA, Sarjito. 2019. Performa pertumbuhan ikan kakap putih (Lates calcalifer Bloch, 1790) yang dibudidayakan dalam sistem keramba jaring apung (KJA). Jurnal Sains Akuakultur Tropis. 3(1): 56-60

Zulpikar, Irawan H, Putra WKA. 2018. Tingkat efisiensi pakan dan pertumbuhan benih ikan bawal bintang dengan pemberiaan dosis recombinant Growth Hormone (rGH) yang berbeda. Intek Akuakultur. 2(2): 58-69 